\title{
Pursuit of the Corynebacterium striatum Type Strain
}

\author{
MARIE B. COYLE, ${ }^{1,2 *}$ REBECCA B. LEONARD, ${ }^{1} \dagger$ AND DAVID J. NOWOWIEJSKI ${ }^{1}$ \\ Department of Laboratory Medicine, Harborview Medical Center, University of Washington, Seattle, \\ Washington 98104, ${ }^{1}$ and Department of Microbiology, University of Washington, Seattle, Washington $98195^{2}$
}

\begin{abstract}
The description of Corynebacterium striatum (Chester 1901) Eberson $1918^{\mathrm{AL}}$ in Bergey's Manual of Systematic Bacteriology has many inconsistencies with the identification scheme from the Centers for Disease Control and Prevention. We have studied the four $C$. striatum reference strains available from the American Type Culture Collection and the National Collection of Type Cultures and found that they fit the Centers for Disease Control and Prevention description of this species. However, it appears that the wrong strains were deposited for this species, because none of the reference strains fits the descriptions in the original publications. This is a substantial case for declaring it a nomen dubium, but the name could be rescued if a careful search reveals a strain that was used in making the original description. It is hoped that some readers may have the missing strains labeled with the early names Bacillus striatus, Bacillus flavidus, or Corynebacterium flavidum.
\end{abstract}

Two major resources for identification of Corynebacterium striatum (Chester 1901) Eberson $1918^{\mathrm{AL}}$ (20) have substantial disagreements in their descriptions of this species $(11,15)$. The purpose of this study was to analyze the original descriptions of organisms presumed by subsequent authors to be $C$. striatum and compare them with all reference strains of this species currently available from the American Type Culture Collection (ATCC) and the National Collection of Type Cultures (NCTC). We have found that none of the four available reference strains of $C$. striatum (ATCC 43735, ATCC 43751, and the type strains, ATCC 6940 and NCTC 764) fits any of the three original descriptions which authors have cited for this species $(17,18,21)$.

The nomenclature of $C$. striatum has had an unusually complex history since it was first described as Bacillus striatus by vonBesser in 1889 (21). Table 1 summarizes the various names attributed to $C$. striatum and shows all publications cited in the various editions of Bergey's manual of determinative bacteriology. In Bergey's manual of systematic bacteriology, $C$. striatum stands as an accepted species and is presented with the complete morphological and biochemical details that were first compiled for the seventh edition of Bergey's manual $(9,11)$. Such agreement on $C$. striatum has not been a consistent feature of past editions of Bergey's manual. The eighth edition (19) listed $C$. striatum under species incertae sedis, and the sixth edition placed it in an appendix of incompletely described organisms while making no attempt to present a description of the species (8). Interestingly, the descriptions of Corynebacterium flavidum found in the first five editions of Bergey's manual (2-6) contained more biochemical details than were presented in their cited source, which was Morse's description of Bacillus flavidus (17). Subsequent Bergey editions (9, $11,19)$ supplemented their description of $C$. striatum with details from Munch-Petersen's characterization of $C$. flavidum (18).

Table 2 summarizes the characteristics of $C$. striatum strains described by vonBesser, Morse, Bergey's manuals, Munch-Petersen, and the Centers for Disease Control (CDC). VonBesser's description of B. striatus albus and $B$. striatus flavus contained detailed descriptions of morpholog-

\footnotetext{
* Corresponding author. Electronic mail address: Coyle@zippy. labmed.washington.edu.

$\dagger$ Present address: ARUP, Salt Lake City, UT 84108.
}

ical features but none of biochemical reactions (21). In 1912, Morse reported that $B$. flavidus was able to produce acid from glucose and maltose but not sucrose and presented a photomicrograph depicting thick cells with distinct bars (17). Eberson concluded that Morse's B. flavidus was identical to vonBesser's $B$. striatus, a single species with the two varieties, albus and flavus (13). The next original paper describing $C$. striatum was not published until 1954, when MunchPetersen isolated bovine coryneforms (C. flavidum) that produced an inhibitor of the beta-hemolysin of Staphylococcus aureus (18). Presumably because of glucose, maltose, and sucrose reactions, Munch-Petersen believed that his isolates matched the $B$. flavidus strains described by Morse fairly well.

The authors of the $C$. striatum sections in recent editions of Bergey's manual made the point that detailed comparisons between human and bovine strains have not been made and that there is considerable doubt whether more than one group of strains is being described under the name $C$.

TABLE 1. Summary of citations in references thought to be describing C. striatum $^{a}$

\begin{tabular}{|c|c|c|c|}
\hline Reference & Yr & Name(s) of organism & References cited \\
\hline $21^{b}$ & 1889 & $\begin{array}{l}\text { B. striatus albus and } \\
\text { B. striatus flavus }\end{array}$ & None \\
\hline 10 & 1901 & B. striatum & 21 \\
\hline $17^{b}$ & 1912 & B. flavidus & None \\
\hline $13^{c}$ & 1918 & C. striatum & $10,17,21$ \\
\hline 14 & 1920 & C. flavidum & 17 \\
\hline 2 & 1923 & C. flavidum & 17 \\
\hline 5 & 1925 & C. flavidum & 17 \\
\hline 6 & 1930 & C. flavidum & 17 \\
\hline 3 & 1934 & C. flavidum & 2,17 \\
\hline 4 & 1939 & C. flavidum & 2,17 \\
\hline 8 & 1948 & C. striatum & $10,13,17,21$ \\
\hline 18 & 1954 & C. flavidum & 4,17 \\
\hline 9 & 1957 & C. striatum & $10,13,17,18,21$ \\
\hline 19 & 1974 & C. striatum & $10,13,17,18$ \\
\hline 11 & 1986 & C. striatum & $10,13,18$ \\
\hline
\end{tabular}

${ }^{a}$ The table only includes references mentioned in various editions of Bergey's manual.

${ }^{b}$ VonBesser and Morse did not cite references for $B$. striatus and $B$. flavidus, respectively.

${ }^{c}$ On the basis of his own studies, Eberson agreed with Morse that vonBesser was dealing with one organism that is capable of producing pigment varying from white to yellow. 
TABLE 2. Comparison of three original descriptions with Bergey's and CDC's summaries of organisms believed to be $C$. striatum

\begin{tabular}{|c|c|c|c|c|c|c|}
\hline Trait & vonBesser (1889) & Morse (1912) & $\begin{array}{c}\text { Bergey (1923 to } \\
1939)\end{array}$ & $\begin{array}{l}\text { Munch-Petersen } \\
(1954)\end{array}$ & Bergey (1986) & $\mathrm{CDC}^{a}$ \\
\hline Name & $\begin{array}{l}\text { B. striatus albus } \\
\text { and } B . \text { striatus } \\
\text { flavus }\end{array}$ & B. flavidus & C. flavidum & C. flavidum & C. striatum & $\begin{array}{l}\text { C. striatum ATCC } \\
6940\end{array}$ \\
\hline \multicolumn{7}{|l|}{$\begin{array}{l}\text { Microscopic ap- } \\
\text { pearance }\end{array}$} \\
\hline Growth medium & $\mathrm{NS}^{b}$ & 24-h serum & NS & 24-h broth & NS & NS \\
\hline Shape & Often curved & Thick forms & Varies considerably & Pleomorphic & $\begin{array}{l}\text { Pleomorphic, often } \\
\text { club shaped }\end{array}$ & $\begin{array}{l}\text { NS (Curved cells } \\
\text { on agar) }\end{array}$ \\
\hline Size & $\begin{array}{l}\text { B. striatus albus } \\
\text { small, approx. } \\
\text { the size of diph- } \\
\text { theria bacillus; } B \text {. } \\
\text { striatus flavus } \\
\text { larger }\end{array}$ & Large & $\begin{array}{l}0.75-1.0 \times 3.0-5.0 \\
\mu \mathrm{m}\end{array}$ & $0.25-0.5 \times 2-3 \mu \mathrm{m}$ & $\begin{array}{l}0.25-0.5 \times 2.0-3.0 \\
\mu \mathrm{m}\end{array}$ & $\begin{array}{l}\text { Short to slightly } \\
\text { long }\end{array}$ \\
\hline $\begin{array}{l}\text { Barring and/or } \\
\text { granulation }\end{array}$ & $\begin{array}{l}\text { Conspicuous } \\
\text { beaded staining } \\
\text { with methylene } \\
\text { blue }\end{array}$ & $\begin{array}{l}\text { Clear-cut bars; pre- } \\
\text { dominant very } \\
\text { large, irregular } \\
\text { Neisser's gran- } \\
\text { ules }\end{array}$ & Barred & $\begin{array}{l}\text { Fairly large meta- } \\
\text { chromatic gran- } \\
\text { ules }\end{array}$ & $\begin{array}{l}\text { Metachromatic } \\
\text { granules often } \\
\text { regularly ar- } \\
\text { ranged to give } \\
\text { segmented effect }\end{array}$ & Beaded \\
\hline Clubbing & $\begin{array}{l}\text { Club forms seen in } \\
\text { older cultures }\end{array}$ & $\begin{array}{l}\text { Photomicrograph } \\
\text { shows no club } \\
\text { forms }{ }^{c}\end{array}$ & Club shaped & Many club shaped & Often clubbed & $\begin{array}{l}\text { Club and dumbbell } \\
\text { forms }\end{array}$ \\
\hline Colonies on agar & $\begin{array}{l}\text { Convex, } \sim 0.5 \mathrm{~mm} \\
\text { diam, large } \\
\text { brown center } \\
\text { surrounded by a } \\
\text { brownish zone } \\
\text { seen with } \times 60 \\
\text { magnification }\end{array}$ & $\mathrm{NS}^{d}$ & $\begin{array}{l}\text { Spreading, adher- } \\
\text { ent, wrinkled, or } \\
\text { corrugated radi- } \\
\text { ally }\end{array}$ & $\begin{array}{l}\text { Growth only visible } \\
\text { after } 48 \mathrm{~h} \text {; day } 5 \text { : } \\
1-1.4 \mathrm{~mm} \text { diam, } \\
\text { white, smooth, } \\
\text { entire, heaped up }\end{array}$ & $\begin{array}{l}\text { Rather slow } \\
\text { growth; white, } \\
\text { smooth, entire; } \\
\text { diam, -1 mm at } \\
48 \mathrm{~h}\end{array}$ & $\begin{array}{l}\text { NS (convex, } \\
\text { smooth; } 2 \mathrm{~mm} \text { in } \\
48 \mathrm{~h} \text { ) }\end{array}$ \\
\hline Pigment on agar & $\begin{array}{l}\text { B. striatus albus, } \\
\text { milky colored; } B \text {. } \\
\text { striatus flavus, } \\
\text { sulfur yellow af- } \\
\text { ter several days }\end{array}$ & NS & Yellowish & $\begin{array}{l}\text { Yellowish-green } \\
\text { pigment, soluble } \\
\text { in medium, pro- } \\
\text { duced by } 8 \\
\text { strains }^{e}\end{array}$ & $\begin{array}{l}\text { Some produce yel- } \\
\text { lowish-green pig- } \\
\text { ment soluble in } \\
\text { medium }\end{array}$ & NS (gray-white) \\
\hline $\begin{array}{l}\text { Pigment in liquid } \\
\text { culture }\end{array}$ & NS & $\begin{array}{l}\text { Yellowish or yel- } \\
\text { low-white }\end{array}$ & NS & White & White & NS (white) \\
\hline Growth in broth & $\begin{array}{l}\text { Little turbidity but } \\
\text { significant sedi- } \\
\text { ment }\end{array}$ & $\begin{array}{l}\text { In serum, heavy } \\
\text { growth, often } \\
\text { noticeably dry } \\
\text { and granular }\end{array}$ & Thin pellicle & $\begin{array}{l}\text { Already visible af- } \\
\text { ter } 24 \text { h; excel- } \\
\text { lent growth, } \\
\text { clear superna- } \\
\text { tant, finely gran- } \\
\text { ular sediment, } \\
\text { easily suspended; } \\
\text { no growth on } \\
\text { surface }\end{array}$ & $\begin{array}{l}\text { Clear supernatant, } \\
\text { no pellicle, finely } \\
\text { granular sedi- } \\
\text { ment }\end{array}$ & $\begin{array}{l}\text { NS (heavy turbid- } \\
\text { ity) }\end{array}$ \\
\hline $\begin{array}{l}\text { Hemolysis on } \\
\text { blood agar }\end{array}$ & NS & NS & $\begin{array}{l}\text { May show slight } \\
\text { hemolysis }\end{array}$ & $\begin{array}{l}\text { Slight hemolysis } \\
\text { around deep but } \\
\text { not surface colo- } \\
\text { nies }\end{array}$ & $\begin{array}{l}\text { Slight hemolysis } \\
\text { around deep col- } \\
\text { onies }\end{array}$ & $\begin{array}{l}\text { Lysis (not hemo- } \\
\text { lytic) }\end{array}$ \\
\hline $\begin{array}{l}\text { Litmus milk reac- } \\
\text { tion }\end{array}$ & NS & NS & $\begin{array}{l}\text { Slightly acid, be- } \\
\text { coming slightly } \\
\text { alkaline }\end{array}$ & $\begin{array}{l}\text { No change in } 5 \\
\text { days; may be } \\
\text { reduced in } 3 \mathrm{wk}\end{array}$ & NS & Indicator reduced \\
\hline Gelatin liquefaction & NS & NS & $-{ }^{b}$ & $\begin{array}{l}\mathrm{d}(11 / 19 \text { weak in } 2 \\
\text { wk })^{b}\end{array}$ & $(\sim 50 \%)$ & - \\
\hline Indole reaction & NS & NS & - & - & - & - \\
\hline $\mathrm{NO}_{3}$ to $\mathrm{NO}_{2}$ & NS & NS & - & - & - & + \\
\hline
\end{tabular}


TABLE 2-Continued

\begin{tabular}{|c|c|c|c|c|c|c|}
\hline Trait & vonBesser (1889) & Morse (1912) & $\begin{array}{c}\text { Bergey (1923 to } \\
1939)\end{array}$ & $\begin{array}{l}\text { Munch-Petersen } \\
\text { (1954) }\end{array}$ & Bergey (1986) & $\mathrm{CDC}^{a}$ \\
\hline \multicolumn{7}{|l|}{$\begin{array}{c}\text { Carbohydrate } \\
\text { acidified }\end{array}$} \\
\hline Glucose & NS & + (always) & + & $+(19 / 19)$ & + & $+(100 \%)$ \\
\hline Maltose & NS & + (usually) & + & $\mathrm{d}(15 / 26)$ & + (usually) & $-(0 \%)$ \\
\hline Glycerol & NS & + (usually) & + & $\mathrm{d}(7 / 23)$ & NS & NS \\
\hline Xylose & NS & NS & NS & $-(0 / 11)$ & NS & $-(0 \%)$ \\
\hline Mannitol & NS & NS & NS & $\mathrm{d}(2 / 14)$ & NS & $-(0 \%)$ \\
\hline Lactose & NS & NS & NS & $+(13 / 14)$ & + (usually) & $-(0 \%)$ \\
\hline Sucrose & NS & - & NS & $-(1 / 14)$ & - (occasionally) & $+(100 \%)$ \\
\hline $\begin{array}{l}\text { Methyl red/ } \\
\text { Voges-Proskauer }\end{array}$ & NS & NS & NS & $\mathrm{d}(2 / 19) /-$ & $-/ N S$ & $d(80 \%) /-(6 \%)$ \\
\hline Metabolism & NS & NS & $\begin{array}{l}\text { Aerobic, } \\
\text { facultative }\end{array}$ & $\begin{array}{l}\text { Aerobic, } \\
\text { facultative }\end{array}$ & $\begin{array}{l}\text { Aerobic, } \\
\text { facultative }\end{array}$ & $\mathrm{A} / \mathrm{A}$ on $\mathrm{TSI}^{g}$ \\
\hline Catalase reaction & NS & NS & NS & + & + & + \\
\hline $\begin{array}{l}\text { Inhibition of beta- } \\
\text { hemolysin of } S \text {. } \\
\text { aureus }\end{array}$ & NS & NS & NS & + & NS & NS $(-)$ \\
\hline \multicolumn{7}{|l|}{$\begin{array}{l}\text { Virulence in } \\
\text { laboratory } \\
\text { animals }\end{array}$} \\
\hline Mice & None & NS & $\mathrm{NS}^{h}$ & $\begin{array}{l}\text { Lethal in 6-13 } \\
\text { days }^{i}\end{array}$ & Fatal & NS \\
\hline Guinea pigs & NS & None $^{j}$ & NS & Lethal in 1-3 days ${ }^{i}$ & Fatal & NS \\
\hline Rabbits & None $^{k}$ & NS & NS & NS & NS & NS \\
\hline Habitat & $\begin{array}{l}\text { Normal respiratory } \\
\text { tract }\end{array}$ & Throat & $\begin{array}{l}\text { Nose and throat, } \\
\text { udders of cows } \\
\text { with mastitis }\end{array}$ & $\begin{array}{l}\text { Infected cow ud- } \\
\text { ders }\end{array}$ & $\begin{array}{l}\text { Human nasophar- } \\
\text { ynx, milk of } \\
\text { cows with masti- } \\
\text { tis }\end{array}$ & NS \\
\hline
\end{tabular}

a Authors' results, when different from those of $\mathrm{CDC}$, are given in parentheses.

${ }^{b}$ Symbols and abbreviations: NS, not specified;,$+ 90 \%$ or more of strains positive;,$- 10 \%$ or fewer strains positive; d, 11 to $89 \%$ of strains positive. Numbers in parentheses indicate number of strains positive out of the total number of strains.

$c$ Photomicrographs of other coryneform groups in Morse's paper did show wedge shapes or club shapes.

" Morse omitted solid media to avoid the pitfalls of earlier methods that named diphtheroids on the basis of "slight pecularities in morphology, etc."

$e$ Munch-Petersen did not clearly specify whether the total number of strains studied for pigment production was 19 , 26 , or 31 .

$f^{f}$ Implied but not specifically stated.

$g$ Acid slant and butt on triple sugar iron agar.

${ }^{h}$ These references stated that $C$. flavidum is pathogenic for unspecified types of laboratory animals.

${ }^{i}$ Intramuscular inoculations.

${ }^{j}$ Subcutaneous inoculations of an unspecified small number of strains had no effect.

${ }^{k}$ Hemorrhagic reddening at the subcutaneous injection site resolved after 2 days. Intraperitoneal and intravenous injections caused no reaction.

$t$ The paper states that "similar organisms have been found in udders of cows with mammitis."

striatum $(11,19)$. On the basis of the morphology and virulence descriptions from Munch-Petersen and Morse, it seems highly unlikely that the $C$. flavidum from the milk of cows with mastitis was the same as Morse's B. flavidus from human specimens submitted to rule out diphtheria. $C$. flavi$d u m$ did not have the clear-cut bars of $B$. flavidus, whereas the club shapes that were reported to be common in $C$. flavidum cells are not apparent in Morse's photomicrographs of $B$. flavidus $(17,18)$. However, it is difficult to directly compare morphologic descriptions in the two studies, because Morse avoided the use of solid media. A comparison of the virulence studies of Morse and Munch-Petersen provides further evidence that they were dealing with two different organisms (Table 2).

The fact that Morse and Munch-Petersen probably were describing different organisms might not cause much concern if the type strain of $C$. striatum (ATCC 6940) actually conformed to either author's description. However, we have studied the four $C$. striatum strains from both the ATCC and the NCTC and found that none of them fits the description by either Munch-Petersen or Morse. Surprisingly, molecular and biochemical comparisons of all ATCC and NCTC strains of $C$. striatum and Corynebacterium xerosis have revealed that all of the reference strains of $C$. striatum are closely related to three reference strains of $C$. xerosis (ATCC 7094, ATCC 9016, and NCTC 9755) (12).

The reactions of $C$. striatum in the $\mathrm{CDC}$ system and Bergey's differ for 4 of the 13 biochemical tests that they have in common (nitrate reduction, maltose, lactose, and sucrose) $(11,15)$. These discrepancies can be explained by the fact that the Bergey descriptions are based on the published description by Munch-Petersen (12a), whereas the CDC description is based on reactions of the currently available type strain, ATCC 6940 . As summarized in Table 2 , we have found that the $C$. striatum reference strains conform to the CDC description, with the single exception 
that they are not hemolytic on sheep blood agar. We are not aware of recent isolations of organisms that fit the description of $C$. striatum found in reference 11.

In cases such as this, when there is no possibility of the type being a mutant of the original, the name would become a nomen dubium (rule 56a, Bacteriological code) and should be referred to the Judicial Commission for a formal rejection, justified by the lack of accord between the properties of the type and the description. However, if a careful search reveals a strain or strains used in the original description agreeing in its characteristics, then a neotype can be proposed (rule 18c). Therefore, this paper forms part of the careful search. It is hoped that some readers will recognize that they have old stock cultures labeled $B$. striatus, $B$. flavidus, $C$. flavidum, or $C$. striatum that actually fit an original description of any of these organisms as summarized in Table 2. Such strains could then be studied by modern taxonomic methods and assigned to the correct taxa. The English literature contains only three reports of infections due to $C$. striatum $(1,7)$ or $C$. striatum-like organisms (16). Although this may simply reflect the relatively low virulence of this species, it seems likely that many potential case reports were not written because the conflicting identification schemes for $C$. striatum precluded definitive identifications.

We thank Sue E. Gavin for an excellent review of the manuscript and Gertrud Schmidt for a skillful translation of the vonBesser paper.

\section{REFERENCES}

1. Barr, J. G., and P. G. Murphy. 1986. Corynebacterium striatum: an unusual organism isolated in pure culture from sputum. J. Infect. 13:297-298.

2. Bergey, D. H., R. S. Breed, B. W. Hammer, F. C. Harrison, and F. M. Huntoon. 1923. Bergey's manual of determinative bacteriology, 1st ed. The Williams and Wilkins Co., Baltimore.

3. Bergey, D. H., R. S. Breed, B. W. Hammer, F. M. Huntoon, E. G. D. Murray, and F. C. Harrison. 1934. Bergey's manual of determinative bacteriology, 4th ed. The Williams and Wilkins Co., Baltimore.

4. Bergey, D. H., R. S. Breed, E. G. D. Murray, and P. A. Hitchens. 1939. Bergey's manual of determinative bacteriology, 5th ed. The Williams and Wilkins Co., Baltimore.

5. Bergey, D. H., F. C. Harrison, R. S. Breed, B. W. Hammer, and F. M. Huntoon. 1925. Bergey's manual of determinative bacteriology, 2nd ed. The Williams and Wilkins Co., Baltimore.

6. Bergey, D. H., F. C. Harrison, R. S. Breed, B. W. Hammer, and F. M. Huntoon. 1930. Bergey's manual of determinative bacte- riology, 3rd ed. The Williams and Wilkins Co., Baltimore.

7. Bowstead, T. T., and S. M. Santiago. 1980. Pleuropulmonary infection due to Corynebacterium striatum. Br. J. Dis. Chest 74:198-200.

8. Breed, R. S., E. G. D. Murray, and P. A. Hitchens. 1948. Bergey's manual of determinative bacteriology, 6th ed. The Williams and Wilkins Co., Baltimore.

9. Breed, R. S., E. G. D. Murray, and N. R. Smith. 1957. Bergey's manual of determinative bacteriology, 7 th ed. The Williams and Wilkins Co., Baltimore.

10. Chester, F. D. 1901. A manual of determinative bacteriology. The Macmillan Co., New York.

11. Collins, M. D., and C. S. Cummins. 1986. Genus Corynebacterium, Lehmann and Neumann 1896, p. 1266-1276. In P. H. A. Sneath, N. S. Mair, M. E. Sharpe, and J. G. Holt (ed.), Bergey's manual of systematic bacteriology, vol. 2. The Williams and Wilkins Co., Baltimore.

12. Coyle, M. B., R. B. Leonard, D. J. Nowowiejski, A. Malekniazi, and D. J. Finn. 1993. Evidence of multiple taxa within commercially available reference strains of Corynebacterium xerosis. J. Clin. Microbiol. 31:1788-1793.

12a.Cummins, C. S. Personal communication.

13. Eberson, F. 1918. A bacteriologic study of the diphtheroid organisms with special reference to Hodgkin's disease. J. Infect. Dis. 23:1-41.

14. Holland, D. F. 1920. In C.-E. A. Winslow, J. Broadhurst, R. E. Buchanan, C. Krumwiede, L. A. Rogers, and G. H. Smith. 1920. The families and genera of the bacteria. Final report of the committee of the Society of American Bacteriologists on characterization and classification of bacterial types. J. Bacteriol. 5:191-229.

15. Hollis, D. G., and R. E. Weaver. 1981. Gram-positive organisms: a guide to identification. Special Bacteriology Section, Centers for Disease Control, Atlanta.

16. Markowitz, S. M., and P. E. Coudron. 1990. Native valve endocarditis caused by an organism resembling Corynebacterium striatum. J. Clin. Microbiol. 28:8-10.

17. Morse, M. E. 1912. A study of the diphtheria group of organisms by the biometrical method. J. Infect. Dis. 11:253-285.

18. Munch-Petersen, E. 1954. A corynebacterial agent which protects ruminant erythrocytes against staphylococcal $\beta$ toxin. Aust. J. Exp. Biol. 32:361-368.

19. Rogosa, M., C. S. Cummins, R. A. Lelliott, and R. M. Keddie. 1974. Coryneform group of bacteria, p. 599-632. In R. E. Buchanan and N. E. Gibbons (ed.), Bergey's manual of determinative bacteriology, 8th ed. The Williams and Wilkins Co., Baltimore.

20. Skerman, V. B. D., V. McGowan, and P. H. A. Sneath (ed.) 1980. Approved lists of bacterial names. Int. J. Syst. Bacteriol. 30:225-420.

21. vonBesser, L. 1889. Über die Bakterien der normalen Luftwege. Beitr. Pathol. Anat. Allg. Pathol. 6:331-372. 